\title{
Comparative Characterization of Birch Bark Extracts Encapsulated Inside Polyurethane Microstructures
}

\begin{abstract}
FLORIN BORCAN ${ }^{2 *}$, MARIUS PREDA ${ }^{1 *}$, LIVIA CRISTINA BORCAN², IULIA PINZARU ${ }^{1}$, SORIN FLORESCU2*, EUGEN SISU2, MARIOARA POENARU ${ }^{1}$

${ }^{1}$ Victor Babes University of Medicine and Pharmacy Timisoara, Faculty of Pharmacy, $2^{\text {nd }}$ Eftimie Murgu Sq.,Timisoara, 300041, Romania

${ }^{2}$ Victor Babes University of Medicine and Pharmacy Timisoara, Faculty of Medicine, 2nd Eftimie Murgu Sq.,Timisoara, 300041, Romania

The phytotherapy is based on the consume of fruits, vegetables and medicinal plants; they contain mixtures of bioactive chemical substances (carotenoids, phenolic acids, flavonoids, coumarins, tannins, organosulfur compounds) with synergic effects on the treatment of diseases. Nano- and micro-carriers are very useful drug delivery systems which can improve the transmembrane transfer of natural extracts. In the present study, betulin and two birch bark extracts were encapsulated inside polyurethane microstructures. Structures' size, homogeneity and surface charge were studied using a Zetasizer, while DSC analysis was involved to assay structures' thermal behavior. Irritation effects were monitored by non-invasive techniques on human skin. The results indicate the obtaining of structures with size around $200-250 \mathrm{~nm}$, with a positive surface charge and a verygood thermal stability. The non-irritation potential recommends these structures as a safe delivery system used for natural extracts.
\end{abstract}

Keywords: betulin, drug carrier, erythema, polymer, TEWA, Zeta potential

The phytotherapy (the science of herbs used for health) is thousands of years old: Egyptians, Greeks and Romans used different plants for various treatments, embalming, and cosmetics since $2000 \mathrm{BC}$ according to the old writings of Hippocrates, Dioscorides and Pliny the Elder [1]. This science has developed on an empirical basis, but in which the symbol, analogy and principle of correspondence have played and play a determining role in the choice of plants. With the scientific discoveries of the last century, the phytotherapy has emerged from empiricism, laying the foundation of plant therapeutics on scientific bases and currently, it has become a modern science, a branch of medical sciences [2-4].

One of the most important products based on birch therapies is its water or birch sap, a $100 \%$ natural water that people in rural areas of Europe have been consuming for centuries as a natural detoxification product [5]. It has been demonstrated that it increase the elimination of excess salt, phosphates, uric acid, ammonia and certain drugs (a natural diuretic) - removing these impurities, it helps clean the urinary tract and thereby helps in weight loss; it increase the elimination of different toxins and the liver is not required to put more effort for this [6]. This detoxification leads to the protection of the skin against external factors and it was found that its saponins have lowering cholesterol levels in blood $[7,8]$.

Many scientists still believe that birch bark extracts are more useful than its sap due to an increased content of bioactive agents [9-11]. These extracts contain the following important components: pure terpenoids and their esters with fatty acids (betulin and lupeol), etheric oils, hydrocarbons and their epoxides, steroids (beta-sitosterol), tannins, flavonoids (kaempferol, quercetin, naringenin) and hydroxycoumarins (umbelliferone, esculetin) [12, 13].

Betulin or betulinol (lup-20(29)-ene-3beta,28-diol), $\mathrm{C}_{30} \mathrm{H}_{50} \mathrm{O}_{2}$ (fig. 1), is a very abundant triterpene discovered by J.T. Lowitz two hundred years ago. The compound was also found in elder flowers, some mushrooms and dogrose.

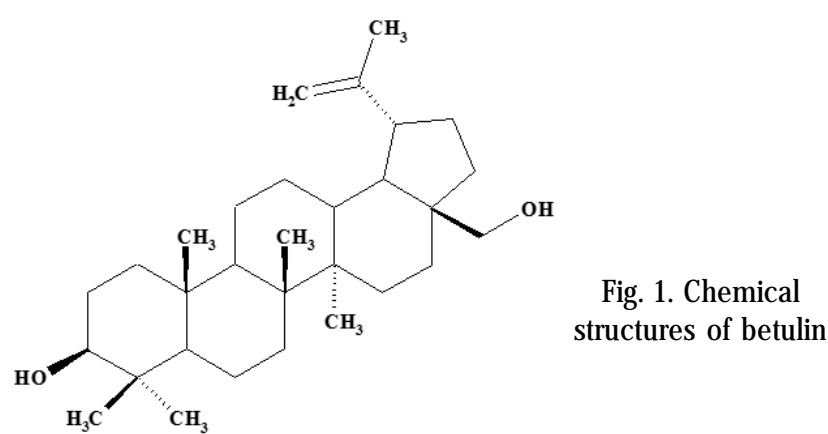

The encapsulation of differentherbal extracts represents a very interesting research field due to the possibility to control their release and to modify the aqueous solubility which influences their therapeutic concentration.

The aim of this study was to obtain very small polyurethane microstructures with birch bark extracts and to characterize these products.

\section{Experimental part}

Pure betulin (BET) was achieved from Aldrich, ethylene glycol (EG) from Lach-Ner s.r.o. (Czech Rep.), isophoronediisocyanate (IPDI), polyethylene glycol, $M=200$ (PEG), the surfactant (Tween ${ }^{\circledR} 20$ ) and the solvent (acetone) from Merck (Germany).

\section{Extraction of bioactive agents}

Two different procedures were used to obtain birch bark extracts. The first extract (BB 1) was obtained using a protocol described by C.A. Dehēlean et al. [14]: the bark of the birch tree was harvested this spring from South-West of Romania (Caras-Severin and Mehedinti counties) and it was extracted with a 96\% 2-propanol solution in a Soxhlet for 6 hours and the product was concentrated using a rotary evaporator. The second extract (BB 2) is based on a procedure described by M.F. Munteanu' et al. [15]: another part of the same birch was extracted with a $70 \%$ ethanol solution for $24 \mathrm{~h}$; the mixture was filtered and centrifuged 
at $3000 \mathrm{rpm}$ for $5 \mathrm{~min}$ and it was concentrated by a rotary evaporator at $90^{\circ} \mathrm{C}$ until constant weight.

\section{Synthesis of polyurethane microstructures}

The multi-step procedure used to synthesize polyurethanes microstructures was presented in our previous papers [16-18]:

- Non-aqueous phase: $1.0 \mathrm{~mL}$ surfactant $\left(\operatorname{Tw}^{-}{ }^{\circledR}{ }^{\circledR} 20\right)$ was mixed with $30 \mathrm{~mL}$ solution IPDI in acetone $(10 \%, \mathrm{v} / \mathrm{v})$ and were magnetic stirred at $450 \mathrm{rpm}$ and $35^{\circ} \mathrm{C}$ for $40 \mathrm{~min}$;

- Aqueous phase: $50 \mathrm{ml}$ mixture of EG, PEG and distilled water $(0.6: 1: 20, \mathrm{v} / \mathrm{v} / \mathrm{v})$ was homogenized at $450 \mathrm{rpm}$ and $35^{\circ} \mathrm{C}$ for $40 \mathrm{~min}$;

- The phases were rapidly mixed under magnetic stirring at $550 \mathrm{rpm}$ and $40^{\circ} \mathrm{C}$; the stirring continued at $550 \mathrm{rpm}$ for $3 \mathrm{~h}$ to ensure the maturation of the microstructures' wall;

- Products' purification: the suspensions were dried as thin layers at $45^{\circ} \mathrm{C}$ for more than $24 \mathrm{~h}$ and then, they were repeatedly washed with a water-acetone mixture (1:1.2, $\mathrm{v} / \mathrm{v})$, and centrifuged.

The experiment was repeated in order to obtain different samples: PU 0 (empty microstructures), BET (structures containing pure betulin), BB 1 (structures with the first birch bark extract) and BB_2 (structures with the second birch bark extract).

The electric charge of the structures' surface and their size were evaluated with a Zetasizer equipment (Cordouan Technol., France) containing a Vasco Particle Size Analyzer and a Wallis Zeta potential Analyzer; the following parameters were set: determination temperature $\left(25^{\circ} \mathrm{C}\right)$, time interval (around $15 \mu \mathrm{s}$ ), channels' no. (around 460), power of laser (85-90\%), acquisition mode (continuous), Pade-Laplace as analysis mode, medium Wallis resolution, and Smoluchowski model as Henry function.

Thermal behavior of polyurethane samples was studied using a Mettler-Toledo DSC1 instrument (Mettler-Toledo, Switzerland) between 20 and $350^{\circ} \mathrm{C}$ in an inertatmosphere using aluminum crucibles and a 5 degree/min heating rate.
Eight healthy human subjects ( 2 men and 6 women, between 20 and 23 years old) were recruited in this study to bioevaluate the irritation potential of the obtained structures. The principles of the Helsinki Declaration and the local jurisdiction have been respected, and the study was first approved by the Ethics Committee of Victor Babes University of Medicine and Pharmacy Timisoara (Romania); every volunteer read and signed an informed consent. All determinations were done with a Multiprobe Adapter System from Courage\&Khazaka (Germany) equipped with a Tewameter ${ }^{\circledR}$ TM300 probe, a Mexameter $^{\circledR}$ MX18 probe, and a Corneometer ${ }^{\circledR}$ CM825 probe. ANOVA was used to determine whether there are any statistically significant differences between the values' groups; the following notations were used on graphs: $*$ for $P \leq 0.05$, ** for $\mathrm{P} \leq 0.01$ and $* * *$ for $\mathrm{P} \leq 0.001$.

\section{Results and discussions}

For more than 2 decades, the nanoparticles, nanotubes and nanocapsules were considered the best new materials used as drug delivery systems. Micro-scale structures were found safer for drug administration to humans nowadays

Table 1 presents the size, homogeneity and surface charge of the obtained polyurethane microparticles.

The increased size in the case of polyurethane structures containing betulin or birch bark extract can be associated with the presence of two functional groups in the structure of betulin, which can play the role of a chain extender inside the polymer. The polydispersity index indicates thatempty structures and those containing betulin are more homogenous than the samples with natural extracts. Positive Zeta potentials between 22 and $25 \mathrm{mV}$ indicate that structures with a medium stability against the tendency to form clusters were obtained in this research.

The polyurethane microstructures present a good stability between 20 and $350^{\circ} \mathrm{C}$ (fig. 2); their Tg values are below $20^{\circ} \mathrm{C}$ and their decomposition begin over $320^{\circ} \mathrm{C}$. The sample of microstructures containing pure betulin

\begin{tabular}{|c|c|c|c|}
\hline \multirow{2}{*}{ Sample code } & \multicolumn{2}{|c|}{ Particle size (nm) } & Zeta potential (mV) Mean \pm \\
\cline { 2 - 3 } & Mean \pm SD & Polydispersity index & \\
\hline PU_0 & $199 \pm 11$ & 0.3 & +24.7 \\
\hline BET & $217 \pm 14$ & 0.3 & +21.2 \\
\hline BB_1 & $248 \pm 19$ & 0.6 & +22.8 \\
\hline BB_2 & $242 \pm 21$ & 0.5 & +22.5 \\
\hline
\end{tabular}

Table 1

THE ZETASIZER CHARACTERISATION OF SYNTHESIZED STRUCTURES

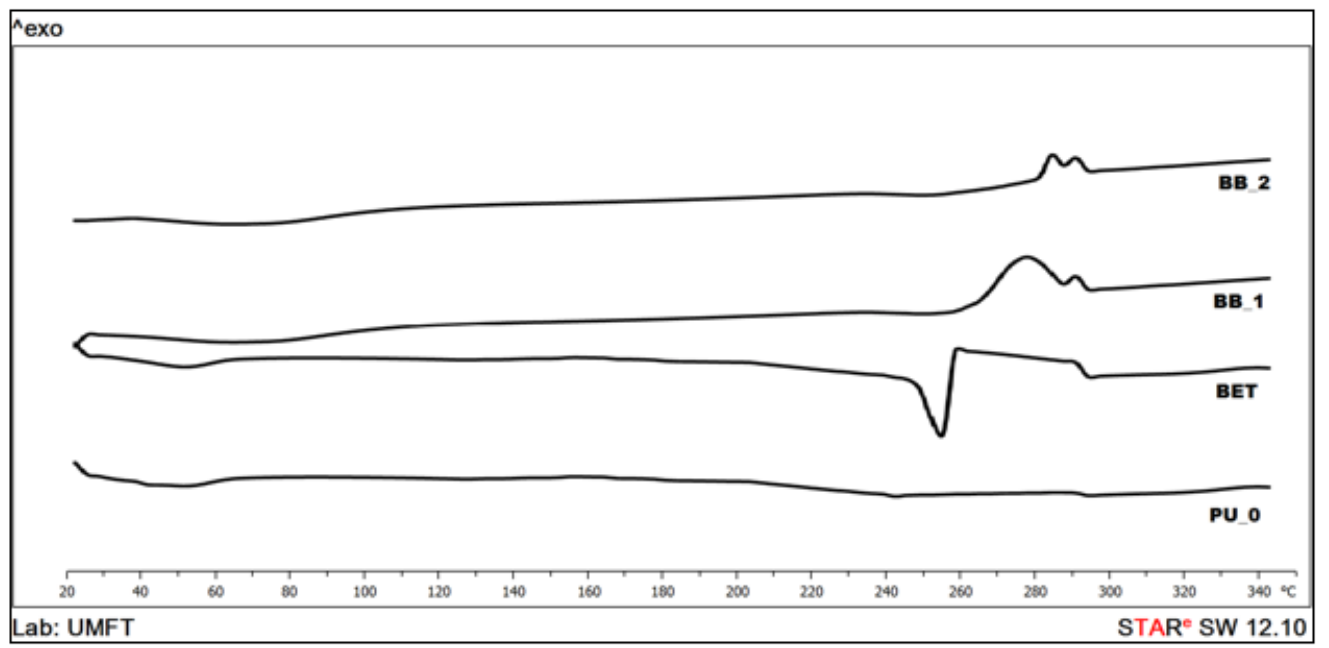

Fig. 2. DSC curves of obtained samples 
exhibits its melting point (around $256^{\circ} \mathrm{C}$ ) probably due to the traces of un-encapsulated active substance.

Modern procedures to evaluate the skin irritation were used in this study: transepidermal water loss (TEWA), erythema and skin hydration. The evolutions of these skin parameters for $48 \mathrm{~h}$ are shown in figure $3 \mathrm{a}-\mathrm{c}$.
The transepidermal water loss is a skin parameter that offers importantinformation aboutan injured skin or about the impact of external agents: physics as extreme temperature, UV exposure or wind and precipitations or chemical aggressive agents as strong acids or other compounds with an increased $\mathrm{pH}$. The modifications of
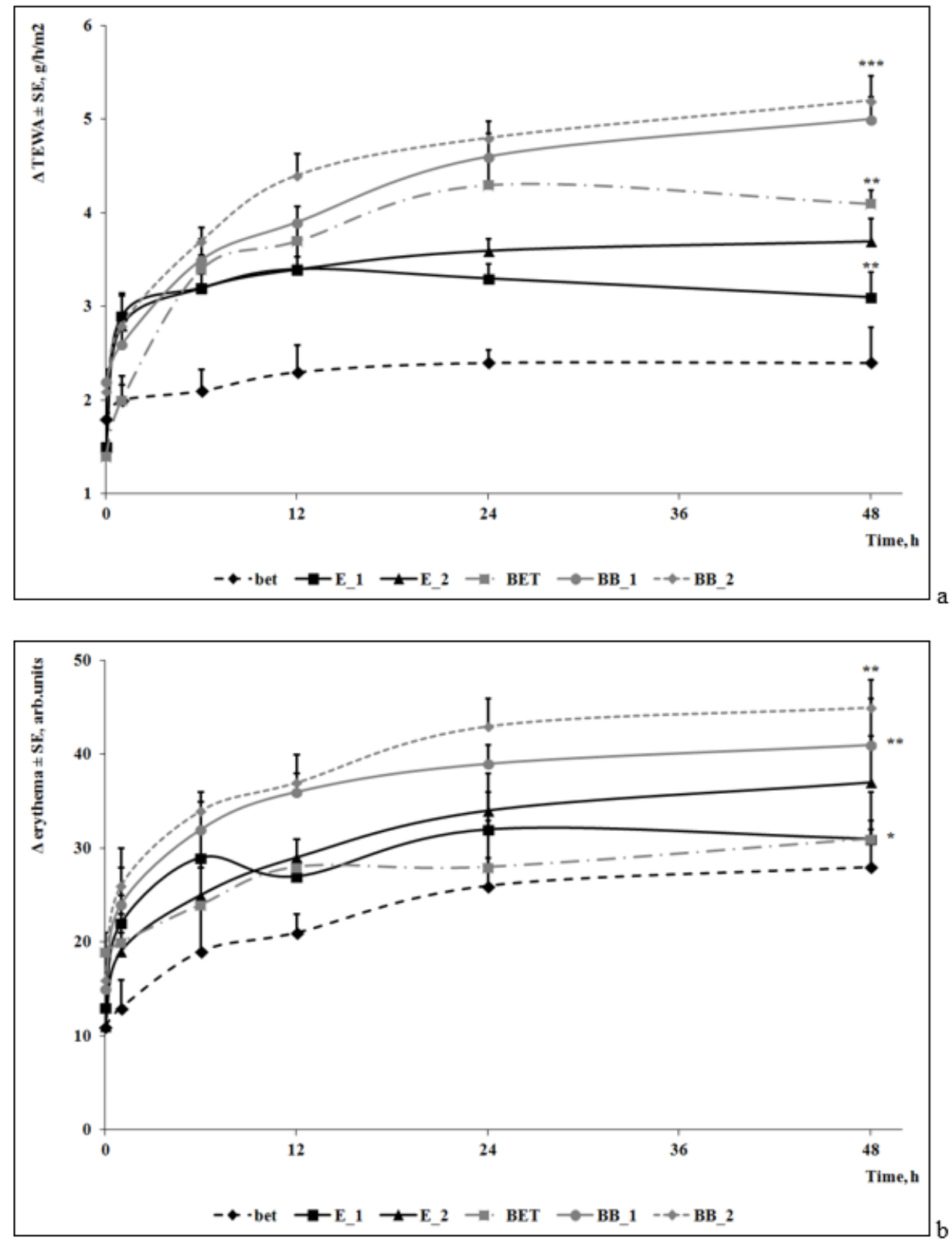

Fig. 3. Changes of skin parameters: (a) TEWL, (b) erythema and (c) hydration

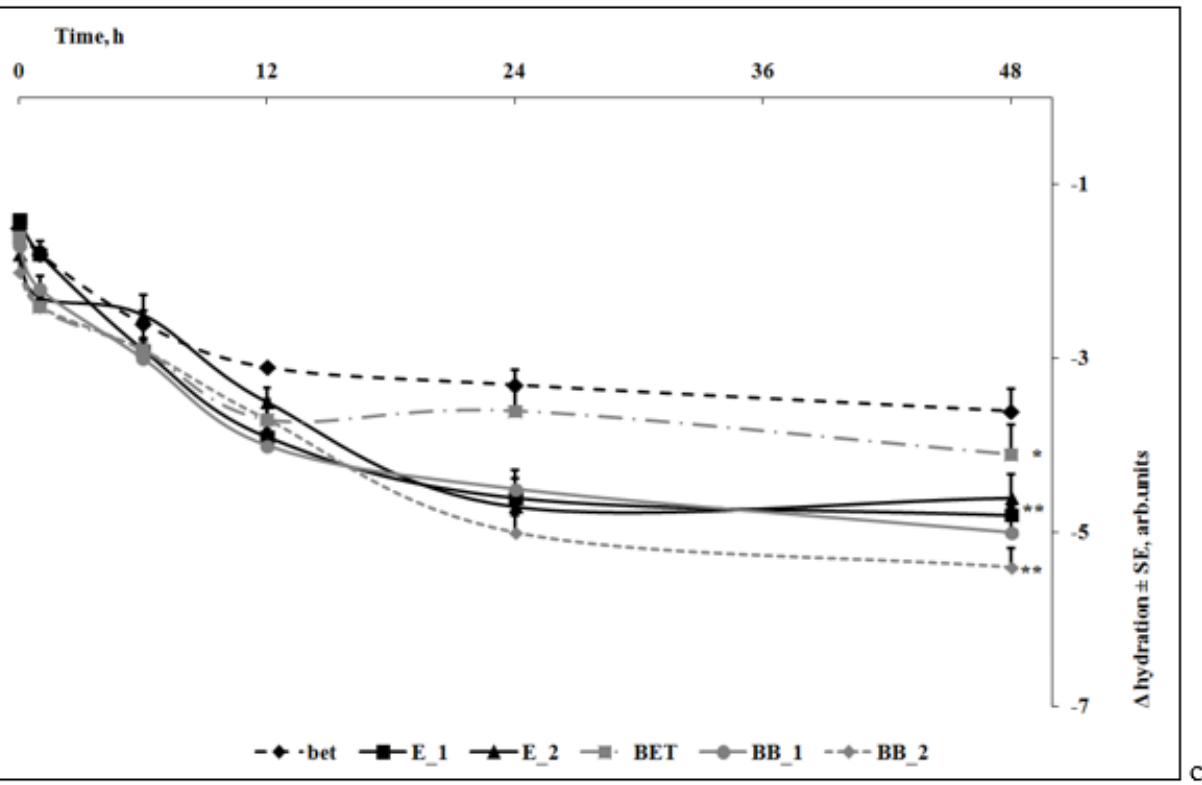


TEWL values are very sensitive and they are observed in every skin experiment; this is the reason why it is very important to observe the amplitude of any modifications. In the case of samples based on betulin and birch bark extracts (bet, E 1 and E_2), TEWL indicates the smallest changes (around $3 \mathrm{~g} / \mathrm{h} / \overline{\mathrm{m}}^{2}$ in 2 days), while the samples based on polyurethane structures presents slightly larger values (around $5 \mathrm{~g} / \mathrm{h} / \mathrm{m}^{2}$ in 2 days).

The observation of erythema modifications is based on the skin absorption-reflection. Similar trends of erythema values were recorded in this two days experiment; very slow growing trends with a maximum around 45 arbitrary units / 2 days indicate that these samples can be considered safe for administration to humans.

The moisture / hydration of skin is very important for its health. The modifications of skin hydration state are inversely proportional to the evolutions of TEWL and erythema. There were seen values decreases for all the tested samples, but the values are inside a narrow range, between 1.5 and 5.5 units, and this is why these modifications are not a problem for humans.

I.M. Citu et al. [19] obtained and characterized a polyurethane carrier used for transmembrane transport of betulin and fatty acids mixtures. They found lower changes of skin moisture in a 7-days experiment done on Balb/c Nude, homozygote mice; thus, it can be appreciated that betulin and fatty acids mixtures present synergistic effects.

\section{Conclusions}

Large hydrophilic molecules, such as most nutrients and certain ions, cannot pass through either the lipid matrix or the ion channels, because they are liposoluble; theirtransfer from one face to the other of the membrane can take place by transport mediated by a conveying molecule, a process known as the facilitated diffusion. This paper describes the obtaining of a polymer carrier based on a mixed process which combines a polyaddition with an emulsification. Microstructures around 200-250 nm, almost homogeneous with a positive surface charge, very stable between 20 and $350^{\circ} \mathrm{C}$ were obtained. The skin irritation was assayed using a few skin parameters such as transepidermal water loss, erythema and skin hydration; no important change was found during these tests. This is the reason why these polyurethane microstructures can be considered as safe products for humans.

\section{References}

1. NUTTON, V. Ancient Medicine, 2nd Edition. New York: Routledge, 2013, p. 5.
2. SAAD, B., SAID, O. Greco-Arab and Islamic Herbal Medicine. New Jersey: John Wiley \& Sons, Inc., 2011, p. 110.

3. RUSSO, E.B. Brit. J. Pharmacol., 163, no. 7, 2011, p. 1344.

4. DEL SOL, A.B., SANCHEZ, L.R.B., NARANJO, R.A., ENGONDO, F.K. J. Pharm. Pharmacognosy Res., 6, no. 5, 2018, p. 374.

5. SVANBERG, I., SOUKAND, R., LUCZAJ , L., KALLE, R., ZYRYANOVA, O., DENES, A., PAPP, N., NEDELCHEVA, A., SESKAUSKAITE, D., KOLODZIEJ SKA-DEGORSKA, I., KOLOSOVA, V. Acta Soc. Botanicorum Pol., 81, no. 4, 2012, p. 343.

6. KUPPER, P., ROHULA, G., INNO, L., OSTONEN, I., SELLIN, A., SOBER, A. Reg. Environ. Change, 17, no. 7, 2017, p. 2149.

7. GRABEK-LEJKO, D., KASPRZYK, I., ZAGULA, G., PUCHALSKI, C. Baltic Forestry, 23, no. 2, 2017, p. 394.

8. KRUPA, K., SZWERC, W., NIZINSKI, P., SLOWIK, K., BLAZEWICZ, A., KOCJAN, R. Curr. Issues Pharm. Med. Sci., 31, no. 2, 2018, p. 57. 9. PFAAR, O., BACHERT, C., KUNA, P., PANZNER, P., DZUPINOVA, M., YU, D., MANTIKOU, E., MOED, H., KLIMEK, L., DE KAM, J. Allergy, 72, Suppl. 103, 2017, p. 275.

10. DING, W.M., ZHANG, S., ZHU, M.X., WANG, S.M., XU, T., QU, H.J ., YU, T., YAN, X.F., WANG, Y. Anti-Cancer Agents Med. Chem., 17, no, 4, 2017, p. 566.

11. LUO, R.L., FANG, D.Y., CHU, P., WU, H.J., ZHANG, Z., TANG, Z.Y. Biomed. Pharmacotherapy, 84, 2016, p. 1321.

12. WARDECKI, T., WERNER, P., THOMAS, M., TEMPLIN, M.F., SCHMIDT, G., BRANDNER, J.M., MERFORT, I. J. Nat. Prod., 79, no. 4, 2016, p. 1112 .

13. CinTA-PInZARU, S., DEHELEAN, C.A., SOICA, C., CULEA, M., BORCAN, F. Chem. Cent. J., 6, no. 1, 2012, p. 67.

14. DEHELEAN, C.A., SOICA, C., LEDETI, I., ALUAS, M., ZUPKO, I., GALUSCAN, A., CINTA-PINZARU, S., MUNTEANU, M. Chem. Cent. J., $\mathbf{6}$, no. 1,2012 , p. 137.

15. MUNTEANU, M.F., ARDELEAN, A., BORCAN, F., TRIFUNSCHI, S.I., GLIGOR, R., ARDELEAN, S.A., CORICOVAC, D., PINZARU, I., ANDRICA, F., BORCAN, L.C. Curr. Drug Deliv., 14, no. 8, 2017, p. 1178.

16. BORCAN, F., SOICA, C.M., DEHELEAN, C.A., GANTA, S., AMIJI, M.M. Rev. Chim. (Bucharest), 63, no. 11, 2012, p. 1164.

17. OPREAN, C., ZAMBORI, C., BORCAN, F., SOICA, C., ZUPKO, I., MINORICS, R., BOJIN, F., AMBRUS, R., MUNTEAN, D., DANCIU, C., PINZARU, I.A., DEHELEAN, C., PAUNESCU, V., TANASIE, G. Pharm. Biol., 54, no. 11, 2016, p. 2714.

18. GALUSCAN, A., JUMANCA, D., BORCAN, F., SOICA, C.M., IONESCU, D., RUSU, L.C., CRAINICEANU, Z. Rev. Chim. (Bucharest), 65, no. 2, 2014, p. 190.

19. CITU, I.M., TOMA, C., TRANDAFIRESCU, C., ANTAL, D., ZAMBORI, C., OPREAN, C., BOJ IN, F., BORCAN, F., PAUNESCU, V., LAZUREANU, V. Rev. Chim. (Bucharest), 66, no. 3, 2015, p. 431.

Manuscript received: 6.05 .2017 